\title{
PENGARUH MODEL PROBLEM BASED LEARNING (PBL) TERHADAP HASIL BELAJAR PESERTA DIDIK KELAS VIII A DI SMPN 1 MANGARAN SITUBONDO
}

\author{
Rahmatillah $^{1}$, Miftahus Surur ${ }^{2}$ \\ ${ }^{1,2}$ STKIP PGRI Situbondo, Jawa Timur Indonesia \\ email: surur.miftah99@gmail.com
}

\begin{abstract}
This study aims to determine the learning outcomes of students who learn using a problem-based learning model, namely Problem Based Learning (PBL). This type of research is quantitative with the pre-experimental design using a one-shot case study. Determination of the sample using purposive sampling method, namely 23 students of class VIII A SMP Negeri 1 Mangaran. Collecting data using test instruments, namely pretest and posttest, which are then analyzed by t-test. The results of the analysis show that tcount> ttable or 4.060 $>2.074$, with a sig value of $0.001<0.05$, so it can be concluded that there is a significant difference in learning outcomes before (pretest) and after (posttest) using the Problem Based Learning (PBL) learning model. This result means that there is an effect of the Problem Based Learning (PBL) model on the learning outcomes of class VIII A students at SMP Negeri 1 Mangaran Situbondo.
\end{abstract}

Keywords: Problem Based Learning (PBL), Learning Outcomes, Students

\begin{abstract}
Abstrak: Penelitian ini bertujuan untuk mengetahui hasil belajar peserta didik yang belajar menggunakan model pembelajaran berbasis masalah yaitu Problem Based Learning (PBL). Jenis penelitian ini bersifat kuantitatif dengan pre-experimental design dengan menggunakan one-shot case study. Penentuan sampel menggunakan metode purposive sampling yaitu 23 peserta didik kelas VIII A SMP Negeri 1 Mangaran. Pengumpulan data dalam penelitian ini menggunakan instrumen test yaitu pre-test dan post-test yang selanjutnya dianalisis dengan uji t-test. Hasil analisis menunjukkan bahwa t_hitung>t_tabel atau $4.060>2,074$, dengan nilai sig 0,001 <0,05 sehingga dapat disimpulkan bahwa terdapat perbedaan yang signifikan terhadap hasil belajar sebelum (pretest) dan sesudah (posttest) menggunakan model pembelajaran Problem Based Learning (PBL). Artinya ada pengaruh model Problem Based Learning (PBL) terhadap hasil belajar peserta didik kelas VIII A di SMP Negeri 1 Mangaran Situbondo.
\end{abstract}

Kata Kunci: Problem Based Learning (PBL), Hasil Belajar, Peserta Didik

\section{PENDAHULUAN}

Pendidikan IPS bertujuan untuk melatih dan memberi bekal kemampuan atau pemahaman dasar pada peserta didik untuk dapat mengembangkan diri sesuai minat, kemampuan, bakat dan lingkungannya. Sebagian peserta didik merasa stress dan bosan dengan pembelajaran ini, sebab banyaknya materi-materi yang harus dihafal, sehingga kemampuan mengingat, kemampuan berpikir logis dan kemampuan konsentrasi menjadi menurun. Hal tersebut menjadi salah satu faktorfaktor penyebab hasil belajar yang kurang optimal, untuk meningkatkan aktivitas 
dan pemahaman peserta didik didalam kelas, maka perlu dibuat suatu rencana pembelajaran yang baik

Hasil belajar merupakan suatu kemampuan yang dimiliki oleh peserta didik setelah peserta didik tersebut mengalami kegiatan belajar. Misalnya, dari tidak mengerti menjadi mengerti, dan dari tidak tahu menjadi tahu (Djonomiarjo, 2020). Proses penilaian hasil belajar dapat memberikan informasi kepada guru tentang kemajuan peserta didik dalam usaha mencapai tujuan melalui kegiatan belajar. (Hasan Baharun, 2015). Penilaian yang dilakukan sifatnya harus komprehensif mencakup ketiga aspek penilaian, yakni: aspek kognitif, aspek afektif, dan aspek psikomotorik. Untuk melihat sejauh mana tujuan pembelajaran tercapai (Amrullah, 2016). Penelitian ini sejalan dengan penelitian Nasution, (2017) yang menyatakan ada 3 indikator hasil belajar yaitu, ranah kognitif, ranah afektif, dan ranah psikomotorik.

Menurut Yasin (2020) Kegiatan pembelajaran apa pun, lebih ditekankan pada proses pembelajaran, bukannya menjadi berfokus pada guru. Sedangkan (Baharun (2015) dalam prosses pembelajaran diperlukan penilaian atau evaluasi untuk mengetahui keberhasilan belajar yang telah ditetapkan. Dengan kata lain, penilaian hasil belajar peserta didik berfungsi sebagai alat untuk mengetahui keberhasilan proses belajar mengajar. Dari beberapa pendapat diatas dapat disimpulkan bahwa hasil belajar merupakan suatu keterampilan yang dimiliki oleh peserta didik setelah peserta didik menjalani aktivitas belajar. Terdapat beberapa faktor yang dapat menyebabkan atau mempengaruhi perbedaan hasil belajar pada kalangan peserta didik, faktor tersebut akan terlihat dalam gejala kognitif, motorik, dan afektif dalam proses belajar maupun hasil belajar. Maka dari itu dibutuhkan penilaian untuk mengetahui tingkat keberhasilan proses dan hasil dari pembelajaran.

Dari hasil pengamatan dikelas dan wawancara dengan guru IPS di SMP Negeri 1 Mangaran menunjukkan bahwa sebagian peserta didik kurang memahami konsep materi pembelajaran dan akibatnya hasil belajar yang diperoleh peserta didik kurang memuaskan. Hal ini disebabkan peserta didik belum terpancing dan belum aktif walaupun guru sudah berusaha. Untuk meningkatkan keaktifan belajar dan hasil belajar peserta didik dibutuhkan pembelajaran yang efektif salah satunya 
dengan menggunakan model Problem Based Learning (PBL) model pembelajaran yang berdasarkan masalah terdiri dari menyuguhkan pada peserta didik situasi masalah yang otentik. Problem Based Learning (PBL) ialah salah satu model pembelajaran yang berbasis masalah, yang dapat membantu pemahaman peserta didik terhadap materi pelajaran, yang memungkinkan dikembangkannya keterampilan berpikir peserta didik (Kodariyati \& Astuti, 2016). Sedangkan menurut Mustofa (2020) Salah satu model pembelajaran yang dapat meningkatkan keterampilan berpikir adalah pembelajaran berbasis masalah.

Dalam proses pembelajaran para peserta didik dapat bekerja didalam kelompok-kelompok kecil dan harus mengidentifikasi apa yang mereka ketahui serta apa yang mereka tidak ketahui dan harus belajar untuk menyelesaikan suatu permasalahan (Fatimah, 2016). Pada model pembelajaran ini, pengetahuan dicari dan dibentuk oleh peserta didik dalam upaya untuk memecahkan contoh-contoh masalah yang dihadapkan pada mereka. Sehingga penggunaan model Problem based learning (PBL) diharapkan dapat menumbuhkan dan meningkatkan hasil belajar dan keaktifan peserta didik dalam kegiatan pembelajaran (Surur, M \& Urfi, 2017).

Langkah-langkah Problem Based Learning (PBL) menurut Arend (2008) yaitu: 1) Orientasi peserta didik pada masalah. 2) Mengorganisasikan peserta didik untuk meneliti. 3) Membantu penyelidikan mandiri dan kelompok. 4) Mengembangkan dan mempresentasikan artefak dan exhibit. 5) Menganalisis dan mengevaluasi proses mengatasi masalah. Model Problem Based Learning (PBL) dipilih karena memiliki beberapa kelebihan, antara lain adalah: 1) Pemecahan masalah yang diberikan dapat menantang dan membangkitkan kemampuan berpikir kritis peserta didik serta bisa memberikan kesenangan untuk mendapatkan suatu pengetahuan baru. 2) Peserta didik menganggap pembelajaran dengan model Problem Based Learning (PBL) lebih disukai dan menyenangkan. 3) Dengan menggunakan model Problem Based Learning (PBL) dalam proses pembelajaran bisa meningkatkan keaktifan peserta didik. 4) Model Problem Based Learning (PBL) bisa membagikan kesempatan kepada peserta didik untuk mengimplementasikan pengetahuan atau pemahaman yang mereka miliki kedalam dunia nyata (Tri Wasonowati et al., 2014). Hal ini dikarenakan pada model Problem 
Based Learning (PBL) peserta didik akan diberikan suatu masalah, dan berdasarkan maslah tersebut peserta didik akan diberikan kesempatan seluas luasnya untuk membangun sendiri konsep dari suatu materi (Untarti, 2015).

Problem based learning (PBL) merupakan pembelajaran berbasis masalah sebagai suatu kondisi bagi peserta didik dalam memecahkan masalah yang ditemui dilingkungan sebagai dasar untuk mendapatkan pengetahuan/pemahaman dan konsep, melalui kemampuan berpikir kritis sehingga penerapan model Problem based learning (PBL) diharapkan dapat menumbuhkan dan meningkatkan hasil belajar serta keaktifan peserta didik dalam kegiatan pembelajaran.

\section{METODE}

Pada penelitian ini, peneliti menggunakan pendekatan penelitian kuantitatif. Untuk mengetahui pengaruh model Problem Based Learning (PBL) Sementara itu, desain yang digunakan dalam penelitian ini ialah Pre-experimental Designs (nondesigns), dengan menggunakan desain One-Shot Case Study. Dalam penelitian ini peneliti menggunakan Pretest sebelum menggunakan perlakuan dan posttes setelah menggunakan perlakuan

Tabel 1 One-Shot Case Study

\section{O}

Keterangan:

$\mathrm{X}=$ Treatment yang diberikan (variabel independent)

$\mathrm{O}=$ Observasi (variabel dependen)

Pengaruh model Problem Based Learning (PBL) (X) terhadap hasil belajar peserta didik (O). Teknik penentuan lokasi yang digunakan oleh peneliti yaitu Purposive Sampling Area. Penelitian ini akan dilakukan di SMP Negeri 1 Mangaran. Dengan responden sebanyak 23 peserta didik kelas VIII A. Cara yang digunakan untuk pengumpulan data meliputi observasi, dokumentasi, dan wawancara. Pengujian hipotesis adalah Uji beda t-tes Paired Sampel Test. Paired Sampel Test adalah salah satu metode pengujian hipotesis komparatif dimana data yang digunakan tidak bebas atau berpasangan. 


\section{HASIL DAN PEMBAHASAN}

\section{Hasil}

Penelitian ini dilaksanakan di SMP Negeri 1 Mangaran pada Semester Genap Tahun Pelajaran 2019/2020. Penelitian dilakukan untuk meningkatkan hasil belajar peserta didik kelas VIII A melalui Model Problem Based Learning (PBL). Data dalam penelitian ini diperoleh peneliti melalui beberapa metode yaitu observasi, dokumentasi, dan wawancara. Metode observasi digunakan peneliti untuk memantau keadaan sekolah meliputi sarana prasarana dan proses pembelajaran IPS. Metode dokumentasi digunakan peneliti untuk memperoleh data-data dari sekolah. Sedangkan untuk mengenai data dan informasi dari pihak sekolah mengenai sistem pembelajaran yang dilakukan di sekolah peneliti menggunakan metode wawancara tidak terstruktur (unstructured interview).

Langkah pertama penelitian, peneliti memberikan soal pretest untuk mengetahui hasil belajar peserta didik sebelum menggunakan perlakuan model Problem Based Learning (PBL), dan posttest setelah diberikan perlakuan menggunakan model Problem Based Learning (PBL). Adapun tabel hasil pretest dan posttest.

Tabel 2 hasil pretest dan posttest

\begin{tabular}{|c|c|c|}
\hline \multicolumn{3}{|c|}{ Metode Problem Based Learning (PBL) } \\
\hline No Absen & Pretest & Posttest \\
\hline 1. & 75 & 75 \\
\hline 2. & 80 & 86 \\
\hline 3. & 75 & 75 \\
\hline 4. & 85 & 90 \\
\hline 5. & 85 & 87 \\
\hline 6. & 80 & 86 \\
\hline 7. & 85 & 87 \\
\hline 8. & 85 & 75 \\
\hline 9. & 75 & 88 \\
\hline 10. & 80 & 98 \\
\hline 11. & 75 & 100 \\
\hline 12. & 70 & 98 \\
\hline 13. & 85 & 100 \\
\hline 14. & 70 & 83 \\
\hline 15. & 70 & 75 \\
\hline 16. & 70 & 75 \\
\hline 17. & 70 & 75 \\
\hline 18. & 75 & 76 \\
\hline 19. & 70 & 75 \\
\hline 20. & 75 & 77 \\
\hline 21. & 80 & 85 \\
\hline 22. & 75 & 77 \\
\hline 23. & 75 & 89 \\
\hline$\sum$ & 1765 & 1932 \\
\hline $\mathrm{X}$ & 76,7 & 84,0 \\
\hline
\end{tabular}


Pada tabel 2 diketahui nilai posttest lebih besar dari pada nilai pretest dengan perolehan nilai rata-rata posttest sebesar 84,0 sedangkan nilai rata-rata pretest adalah sebesar 76,7, ada peningkatan nilai sebesar 7,3.

Tabel Distribusi Frekuensi

\begin{tabular}{|c|c|c|}
\hline Interval & Frekunesi & Persentase \\
\hline $70-72$ & 6 & $26,1 \%$ \\
\hline $73-75$ & 8 & $34,8 \%$ \\
\hline $76-78$ & 0 & $0 \%$ \\
\hline $79-81$ & 4 & $17,4 \%$ \\
\hline $82-84$ & 0 & $0 \%$ \\
\hline $85-87$ & 5 & $21,7 \%$ \\
\hline Jumlah & 23 & $100 \%$ \\
\hline \\
$\frac{\boldsymbol{F}}{\boldsymbol{N}} \boldsymbol{x} \mathbf{1 0 0} \%=\frac{\mathbf{6}}{\mathbf{2 3}}=\mathbf{2 6 , 1}$ \\
\hline
\end{tabular}

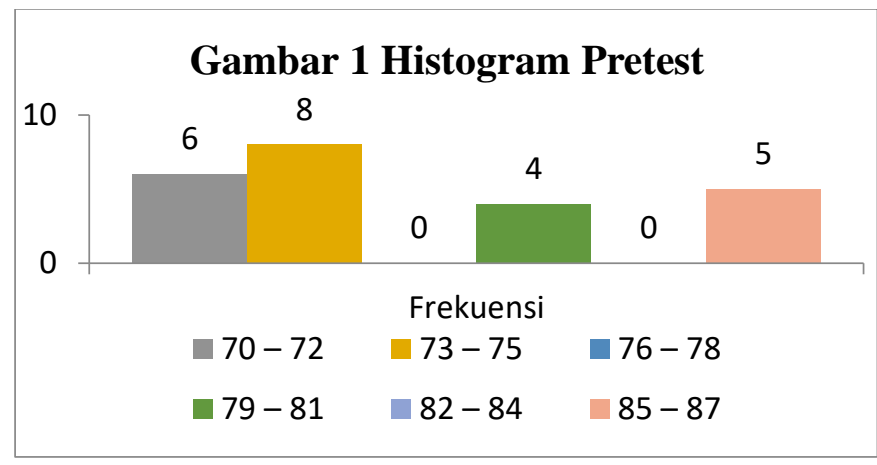

Pada gambar 1 histogram distribusi frekuensi pretest peserta didik dapat diketahui bahwa frekuensi terbesar berada pada interval 73-75 dengan sebesar 8, sedangkan frekuensi terkecil terletak pada interval 76-78 dan 82-84 dengan frekuensi sebesar 0 .

Tabel Distribusi Frekuensi

\begin{tabular}{|c|c|c|}
\hline Interval & Frekunesi & Presentase \\
\hline $75-79$ & 10 & $43,5 \%$ \\
\hline $80-84$ & 1 & $4,3 \%$ \\
\hline $85-89$ & 7 & $30,5 \%$ \\
\hline $90-94$ & 1 & $4,3 \%$ \\
\hline $95-99$ & 2 & $8,7 \%$ \\
\hline $100-104$ & 2 & $8,7 \%$ \\
\hline Jumlah & 23 & $100 \%$ \\
\hline \\
N $\boldsymbol{N} \mathbf{1 0 0} \%=\frac{\mathbf{1 0}}{\mathbf{2 3}}=\mathbf{4 3 , 5}$ \\
\hline
\end{tabular}

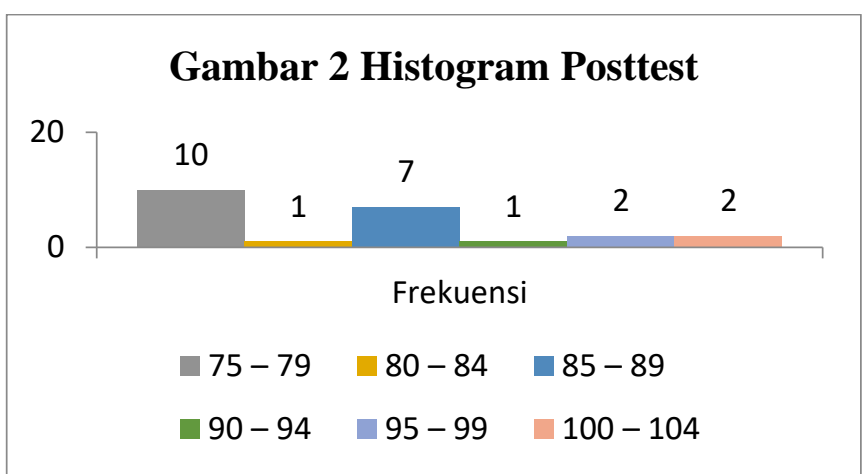

Pada gambar 2 histogram distribusi frekuensi posttest peserta didik dapat diketahui bahwa frekuensi terbesar berada pada interval 75-79 dengan sebesar 10, sedangkan frekuensi terkecil terletak pada interval 80-84 dan 95-99 dengan frekuensi sebesar 1 . 
Table 3 perhitungan $t-$ test dengan SPSS 25.0

\begin{tabular}{llrr|r|r}
\multicolumn{7}{c}{ Paired Samples Statistics } \\
& & Mean & N & Std. Deviation & Std. Error Mean \\
\hline Pair 1 & Pre Test & 76.74 & 23 & 5.561 & 1.160 \\
\cline { 2 - 6 } & Post Test & 84.00 & 23 & 8.888 & 1.853 \\
\hline
\end{tabular}

Berdasarkan tabel tersebut menunjukkan bahwa nilai pretest diperoleh nilai rata-rata hasil belajar atau mean sebesar 76,74. Sedangkan untuk nilai posttest diperoleh nilai rata-rata hasil belajar sebesar 84,00. Jumlah responden atau peserta didik yang digunakan sebagai sampel penelitian sebanyak 23 peserta didik. Untuk nilai standar deviasi Std. Deviation pada pretest sebesar 5,561 dan posttest sebesar 8,888. Terakhir Std. Eror Mean untuk pretest sebesar 1,160 dan untuk posttest 1,853. Dengan ini dapat dikatakan bahwa peserta didik yang menggunakan model Problem Based Learning (PBL) lebih tinggi dibandingkan dengan peserta didik sebelum menggunakan Problem Based Learning (PBL).

Tabael 4 perhitungan $t$ - test dengan SPSS 25.0

\begin{tabular}{ll|l|r|r}
\multicolumn{9}{c}{ Paired Samples Correlations } \\
& & $\mathrm{N}$ & Correlation & \multicolumn{1}{c}{ Sig. } \\
\hline Pair 1 & Pre Test \& Post Test & 23 & .368 & .084 \\
\hline
\end{tabular}

Berdasarkan tabel 4 di atas diketahui nilai koefesien korelasi sebesar 0.368 dengan nilai sig sebesar 0,084. Karena nilai sig 0,084 > 0,05, maka dapat dikatakan bahwa tidak ada hubungan antara posttest dengan pretest.

Tabael 5 perhitungan $t$-test dengan SPSS 25.0

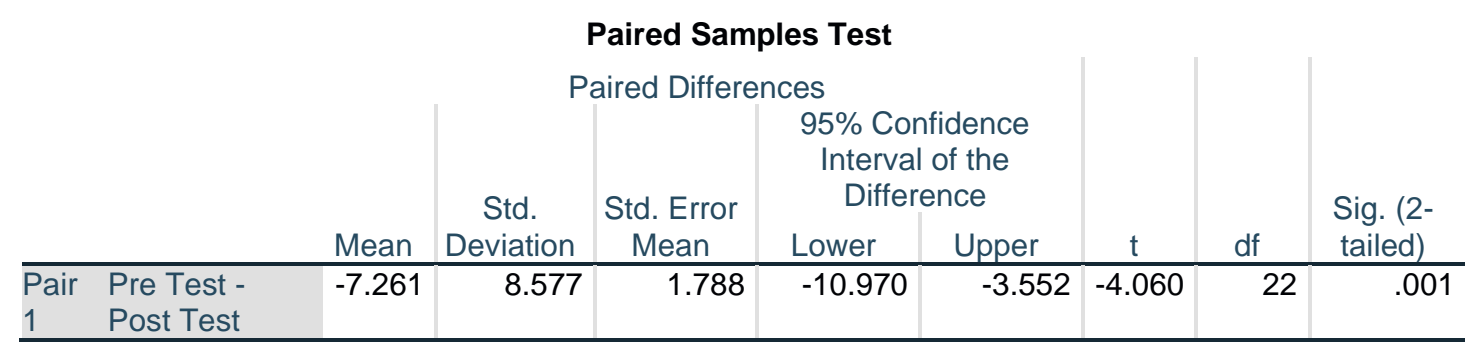

a. Menentukan hipotesis

$\mathrm{H}_{\mathrm{a}}$ : Terdapat pengaruh yang signifikan pada model Problem Based Learning (PBL) terhadap hasil belajar peserta didik pada mata pelajaran IPS materi Perdagangan Antardaerah atau Antarpulau dan Perdagangan Internasional 
Kelas VIII di SMP Negeri 1 Mangaran Semester Genap Tahun Pelajaran $2019 / 2020$.

b. Menentukan dasar pengambilan keputusan

1) Berdasarkan sig

Jika sig $<0,05$, maka $\mathrm{H}_{\mathrm{a}}$ diterima dan $\mathrm{H}_{0}$ ditolak

Jika sig $>0,05$, maka $\mathrm{H}_{0}$ diterima dan $\mathrm{H}_{\mathrm{a}}$ ditolak

Pada table 5 paired sampel test berada di atas nilai sig menunjukkan angka $0,001<0,05$ maka $\mathrm{H}_{\mathrm{a}}$ diterima dan $\mathrm{H}_{0}$ ditolak. Sehingga dapat disimpulkan bahwa ada perbedaan rata-rata antara hasil pretest dengan posttest yang artinya ada pengaruh model Problem Based Learning (PBL) terhadap hasil belajar peserta didik kelas VIII SMP Negeri 1 Mangaran semester II tahun pelajaran 2019/2020.

Tabel paired sampel test di atas juga menunjukan mengenai nilai mean paired differences sebesar -7.261. nilai ini menunjukkan selisih antara nilai hasil belajar pretest dan posttest.

2) Berdasarkan t-hitung

Jika t-hitung > t-tabel, maka $\mathrm{H}_{\mathrm{a}}$ diterima dan $\mathrm{H}_{0}$ ditolak

Jika t-hitung < t-tabel, maka $\mathrm{H}_{0}$ diterima dan $\mathrm{H}_{\mathrm{a}}$ ditolak

Berdasarkan tabel 4 paired sampel test di atas diketahui $t_{\text {hitung }}$ bernilai negatif yaitu sebesar $-4,060$. $t_{\text {hitung }}$ bernilai negatif karena disebabkan nilai rata-rata hasil belejar pretest lebih kecil atau lebih rendah dari pada nilai hasil belajar posttest. Dalam kondisi masalah seperti ini maka nilai $t_{\text {hitung }}$ negatif dapat bermakna positif, sehingga nilai $t_{\text {hitung }}$ menjadi 4,060 .

Selanjutnya tahap mencari nilai $t_{\text {tabel }}$, dimana $t_{\text {tabel }}$ dicari berdasarkan nilai df (degree offreedom $)=N-k$, khusus paired sample test $\mathrm{df}=N-1$ atau derajat kebebasan. Berdasarkan tabel 4.6 paired sampel test di atas diketahui nilai df sebesar 22 dan nilai 0,05/2 sama dengan 0,025. Diketahui nilai $t_{\text {hitung }}=4.060$ dan nilai $t_{\text {tabel }}=2,074$, berarti nilai $t_{\text {tabel }}=2,074<t_{\text {hitung }}=4.060 \mathrm{H}_{\mathrm{a}}$ diterima. Artinya ada pengaruh model Problem Based Learning (PBL) terhadap hasil belajar peserta didik kelas VIII A di SMP Negeri 1 Mangaran semester Genap tahun pelajaran 2019/2020. Dapat dipahami bahwa terdapat perbedaan antara peserta didik yang belajar menggunakan model Problem Based Learning (PBL) dan peserta didik sebelum belajar menggunakan model Problem Based Learning (PBL). 
Sehingga dapat disimpulkan bahwa ada pengaruh yang signifikan pada model pembelajaran Problem Based Learning (PBL) terhadap hasil belajar peserta didik kelas VIII A di SMP Negeri 1 Mangaran semester Genap tahun pelajaran 2019/2020.

\section{Pembahasan}

Penelitian ini dilakukan di SMP Negeri 1 Mangaran kelas VIII A semester Genap tahun pelajaran 2019/2020 dengan menerapkan model pembelajaran Problem Based Learning (PBL) terhadap hasil belajar peserta didik pada materi Perdagangan Antardaerah atau Antarpulau dan Perdagangan Internasional. Berdasarkan pengukuran dan analisis data yang telah dilakukan hasil penelitian ini menunjukkan bahwa model Problem Based Learning (PBL) memiliki pengaruh yang sangat tinggi terhadap hasil belajar peserta didik. Hal ini dapat dibuktikan dengan perbedaan awal peserta didik sebelum dan sesudah diajar menggunakan model pembelajaran Problem Based Learning (PBL) yang membuat peserta didik lebih aktif dalam kegiatan pembelajaran.

Hal ini diperkuat oleh hasil nilai rata-rata pretest dan posttest, perolehan nilai pretest sebesar 76,7 sedangkan perolehan nilai posttest sebesar 84,0 dengan selisih nilah 7,3. Hal ini membuktikan bahwa perolehan hasil belajar posttest lebih beasar dari pada hasil belajar pretest. Peningkatan hasil posttest diperkirakan karena adanya pengaruh model pembelajaran Problem Based Learning (PBL). Hal ini ditunjukkan saat proses pembelajaran berlangsung, dimana peserta didik lebih fokus, aktif, kritis, serta dapat mempertahankan jawabannya menggunakan dasar pengetahuan teori-teori yang sudah ada. Berbeda dengan keadaan sebelumnya peserta kebanyakan tidak memperhatikan materi dikarenakan mereka merasa bosan.

Ini menggambarkan bahwa model pembelajaran yang diterapkan haruslah sesuai dengan mata pelajaran yang diajarkan. Jika peserta didik diberikan orientasi terhadap masalah-masalah yang nyata dalam pembelajaran maka kemampuan berpikir kritis peserta didik akan semakin tinggi serta dapat meningkatkan hasil belajar peserta didik. Hal ini sesuai dengan penelitian (Widodo \& Widayanti, 2014), (Djonomiarjo, 2020), dan (Hendriana, 2018) yang menyatakan model pembelajaran Problem Based Learning (PBL) berpengaruh terhadap hasil belajar. 


\section{KESIMPULAN}

Berdasarkan hasil penelitian dan analisis data yang telah dilakukan oleh peneliti dapat disimpulkan bahwa terdapat pengaruh yang signifikan pada model pembelajaran Problem Based Learning (PBL) terhadap hasil belajar peserta didik pada mata pelajaran IPS materi Perdagangan Antardaerah atau Antarpulau dan Perdagangan Internasional kelas VIII A di SMP Negeri 1 Mangaran Semester Genap Tahun Pelajaran 2019/2020.

\section{DAFTAR RUJUKAN}

Amrullah, A. (2016). Pengaruh Model Pembelajaran Problem Based Learning Terhadap Hasil Belajar Biologi Siswa Pada Konsep Fungi. Universitas Islam Negeri Syarif Hidayatullah Jakarta.

Arend, R. (2008). Learning to Teach (Belajar untuk Mengajar) (7 (ed.)). Pustaka Pelajar.

Djonomiarjo, T. (2020). Pengaruh Model Problem Based Learning Terhadap Hasil

Belajar. Aksara: Jurnal Ilmu Pendidikan Nonformal, 5(1), 39. https://doi.org/10.37905/aksara.5.1.39-46.2019

Fatimah, F. (2016). Kemampuan Komunikasi Matematis dan Pemecahan Masalah

Melalui Problem Based-Learning. Jurnal Penelitian Dan Evaluasi Pendidikan, 14(5), 68-74. https://doi.org/10.11124/JBISRIR-2016-001623

Hasan Baharun. (2015). Penerapan Pembelajaran Active Learning Untuk Meningkatkan Hasil Belajar Siswa Di Madrasah. Jurnal Pendidikan Pedagogik, 01(01), 39.

Hendriana, E. C. (2018). Pengaruh Model Pembelajaran Problem Based Learning Dan Gaya Belajar Auditorial Terhadap Hasil Belajar IPS di Sekolah Dasar. JPDI (Jurnal Pendidikan Dasar Indonesia), 3(1), 1. https://doi.org/10.26737/jpdi.v3i1.484

Kodariyati, L., \& Astuti, B. (2016). Pengaruh Model Pbl Terhadap Kemampuan Komunikasi Dan Pemecahan Masalah Matematika Siswa Kelas V Sd. Jurnal Prima Edukasia, 4(1), 93. https://doi.org/10.21831/jpe.v4i1.7713

Mustofa, R. F. (2020). The Effect of Problem-Based Learning on Lateral Thinking Skills. International Journal of Instruction, 13(1). 
Nasution, M. K. (2017). Penggunaan Metode Pembelajaran Dalam Peningkatan Hasil Belajar Siswa. Jurnal Ilmiah Bidang Pendidikan, 11(1), 9-16.

Surur, M \& Urfi, R. (2017). Penerapan Model Problem Based Learning Menggunakan Index Card Macht untuk Meningkatkan Aktivitas dan Hasil Belajar Siswa Kelas X. Jurnal Pendidikan Edutama, 4(2), 11-18. https://doi.org/http://dx.doi.org/10.30734/jpe.v4i2.51

Tri Wasonowati, R., Redjeki, T., \& Ariani, S. (2014). Penerapan Model Problem Based Learning ( $\mathrm{Pbl}$ ) Pada Pembelajaran Hukum - Hukum Dasar Kimia Ditinjau Dari Aktivitas Dan Hasil Belajar Siswa Kelas X Ipa Sma Negeri 2 Surakarta Tahun Pelajaran 2013/2014. Jurnal Pendidikan Kimia, 3(3), 66-75.

Untarti, R. (2015). Efektifitas Problem Based Learning (PBL) terhadap Kemampuan Pemecahan Masalah Mahasiswa pada Mata Kuliah Statistika Inferensia. Jurnal Pendidikan, 1-12.

Widodo, \& Widayanti, L. (2014). Peningkatan Aktivitas Belajar dan Hasil Belajar Siswa dengan Metode Problem Based Learning pada Siswa Kelas VIIA MTs Negeri Donomulyo Kulon Progo Tahun Pelajaran 2012/2013. Jurnal Fisika Indonesia, 17(49), 32-35. https://doi.org/10.22146/jfi.24410

Yasin, B. (2020). The Effect of English Teacher' s Instructional Management Skills on Beginner Students ' Achievement and Perception. International Journal of Instruction, 13(4). 